\title{
Monitoring the sustainability of in mine degasification boreholes
}

\author{
Oleg Tailakov*, Evgeny Saltymakov, and Sergey Kolesnichenko \\ Federal Research Center for Coal and Coal Chemistry SB RAS, 650000, Kemerovo, Russia
}

\begin{abstract}
Effective lengths measurements of boreholes drilled by rotary drilling rigs from mine workings based on the echolocation principle, was implemented. Recommendations for drilling and effective use of geophysical equipment for monitoring the degas boreholes conditions in coal mines were substantiated and formulated.
\end{abstract}

\section{Indroduction}

The efficiency of coal seams degasification depends on sustainability of degasification boreholes used for methane recovery [1,2]. In this case, it is necessary to ensure control of their conditions [3-5]. For this purpose the echolocation method is proposed for application.

\section{Methodologies}

In mine conditions the time interval between initialization and the acoustic signal arrival from the interface between the media is recorded (Fig. 1).

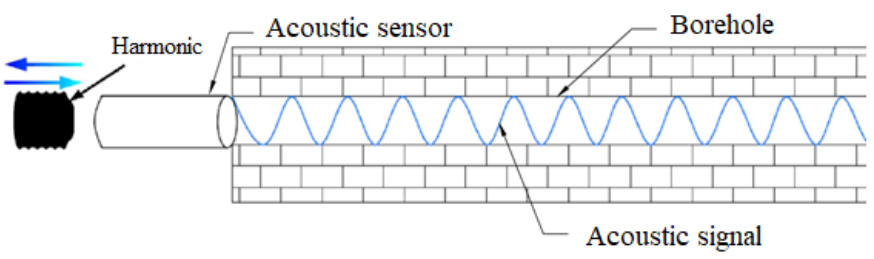

Fig. 1. Schematic representation of the echolocation method

In mine measurements, a set of equipment was used, including devices for the initiation and reception of acoustic signals UPAS (Fig. 2).

The equipment was installed at the wellhead of the borehole and the device was set up into a standby mode for the starting impulse. Then the acoustic signal was generated using the "Harmonic". After the measurements, the equipment was delivered to the laboratory for subsequent processing of the recorded acoustic signals, which included the sequential application of amplitude-frequency characteristics filtering, determination of the reflected

*Corresponding author: tailakov@uglemetan.ru 
acoustic signal first mark, elimination of noise and interference when receiving an acoustic signal (Fig. 3)

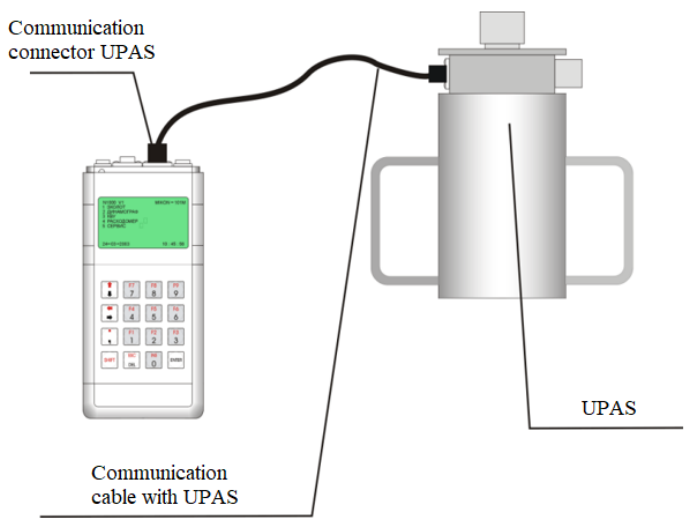

Fig. 2. A set of equipment for measuring degasification boreholes length in mine conditions.

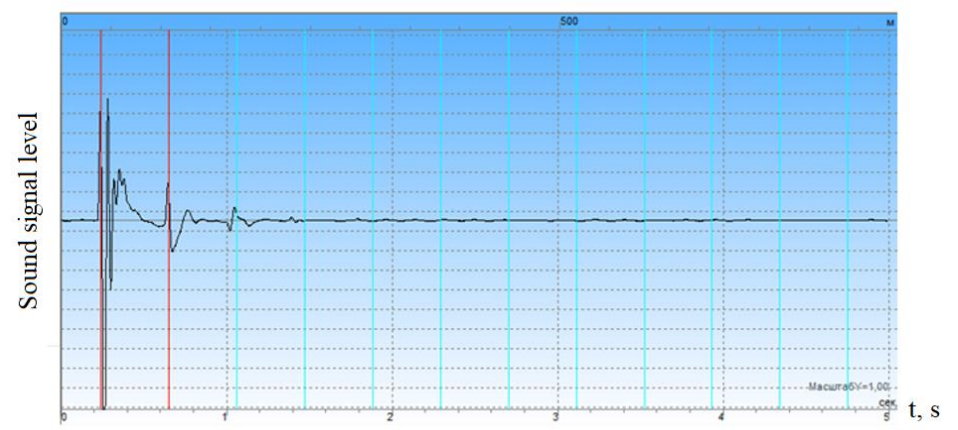

Fig. 3. The resulting echogram of the borehole using filtering of the amplitude-frequency characteristics and the determined first mark of the reflected acoustic signal.

Then the length of boreholes was determined by the formula

$$
L=v \cdot t=\sqrt{\frac{\pi R T}{M}} \cdot t=\alpha \sqrt{T} \cdot t,
$$

where $v$ - acoustic wave velocity $(\mathrm{m} / \mathrm{s}) ; t$ - acoustic wave travel time (s); $\gamma$ - adiabatic exponent; $R$ - gas universal constant; $T$ - absolute temperature $\left({ }^{\circ} \mathrm{K}\right)$; $M$ - molar mass of the gas mixture (g/mol); $\alpha=\sqrt{\eta R / M}$ [5].

\section{Equations and mathematics}

The results of length measurements of the horizontal degasification boreholes drilled from the mine workings in one of the coal mines in the Leninsky geological and economic region of Kuzbass, as well as the methane content in them, are summarized and shown in Table 1. 
Table 1. Results of monitoring changes in boreholes length and methane concentration at wellheads.

\begin{tabular}{|c|c|c|c|c|c|c|c|}
\hline \multirow{2}{*}{ 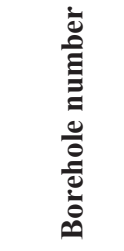 } & \multirow{2}{*}{ 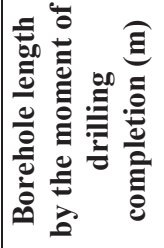 } & \multirow{2}{*}{ 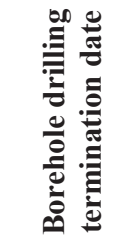 } & \multicolumn{3}{|c|}{ Office processing results } & \multirow{2}{*}{ 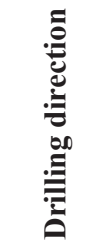 } & \multirow{2}{*}{ 离 } \\
\hline & & & 19.06 & 22.06 & 28.06 & & \\
\hline $\begin{array}{c}\text { cluster10 } \\
\text { borehole } \\
\text { No. } 1\end{array}$ & 70 & 18.06 .19 & 68 & 68 & 61 & Roof & 4 \\
\hline $\begin{array}{c}\text { cluster } 3 \\
\text { borehole } \\
\text { No. } 2\end{array}$ & 93 & 18.06 .19 & 18 & 8 & 7 & floor & 6 \\
\hline $\begin{array}{c}\text { cluster } 2 \\
\text { borehole } \\
\text { No. } 1\end{array}$ & 93 & 13.06 .19 & 10 & 9 & 9 & floor & 7 \\
\hline $\begin{array}{c}\text { cluster } 2 \\
\text { borehole } \\
\text { No. } 2\end{array}$ & 93 & 14.06 .19 & 9 & 9 & 11 & floor & 8 \\
\hline $\begin{array}{c}\text { cluster } 2 \\
\text { borehole } \\
\text { No. } 3\end{array}$ & 93 & 15.06 .19 & 6 & 6 & 6 & floor & 7 \\
\hline $\begin{array}{c}\text { cluster } 2 \\
\text { borehole } \\
\text { No. } 4\end{array}$ & 120 & 16.06 .19 & 8 & 7 & 7 & floor & 7 \\
\hline $\begin{array}{c}\text { cluster } 2 \\
\text { borehole } \\
\text { No. } 5\end{array}$ & 150 & 17.06 .19 & 6 & 6 & 6 & floor & 6 \\
\hline $\begin{array}{c}\text { cluster3 } \\
\text { borehole } \\
\text { No. } 1\end{array}$ & 93 & 18.06 .19 & 19 & 11 & 12 & floor & 7 \\
\hline $\begin{array}{c}\text { cluster } 6 \\
\text { borehole } \\
\text { №1 }\end{array}$ & 70 & 9.06 .19 & 65 & 63 & 60 & Roof & 3 \\
\hline $\begin{array}{c}\text { cluster } 8 \\
\text { borehole } \\
\text { №1 }\end{array}$ & 70 & 14.06 .19 & 67 & 67 & 66 & Roof & 4 \\
\hline $\begin{array}{c}\text { cluster } 8 \\
\text { borehole } \\
\text { No. } 2\end{array}$ & 70 & 14.06 .19 & 70 & 69 & 69 & Roof & 3 \\
\hline $\begin{array}{c}\text { cluster } 8 \\
\text { borehole } \\
\text { No. } 3 \\
\end{array}$ & 70 & 15.06.19 & 68 & 68 & 68 & Roof & 4 \\
\hline $\begin{array}{c}\text { cluster } 9 \\
\text { borehole } \\
\text { No. } 1\end{array}$ & 70 & 16.06 .19 & 68 & 64 & 66 & Roof & 4 \\
\hline $\begin{array}{c}\text { cluster } 9 \\
\text { borehole } \\
\text { No. } 2\end{array}$ & 70 & 17.06.19 & 68 & 68 & 68 & Roof & 6 \\
\hline $\begin{array}{c}\text { cluster9 } \\
\text { borehole } \\
\text { No. } 3\end{array}$ & 70 & 17.06 .19 & 70 & 69 & 69 & Roof & 4 \\
\hline
\end{tabular}




\begin{tabular}{|c|c|c|c|c|c|c|c|}
\hline \multirow{2}{*}{ 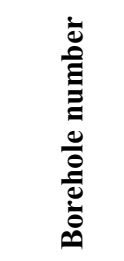 } & \multirow{2}{*}{ 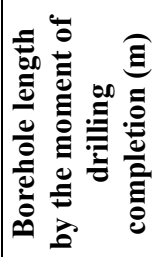 } & \multirow{2}{*}{ 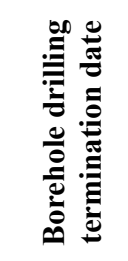 } & \multicolumn{3}{|c|}{ Office processing results } & \multirow{2}{*}{ 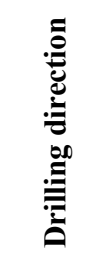 } & \multirow{2}{*}{ 竎 } \\
\hline & & & 19.06 & 22.06 & 28.06 & & \\
\hline $\begin{array}{l}\text { borehole } \\
\text { No. } 6\end{array}$ & 450 & 1.06 .19 & 49 & 40 & 38 & $\begin{array}{l}\text { Coal } \\
\text { seam }\end{array}$ & 6 \\
\hline $\begin{array}{c}\text { borehole } \\
\text { No. } 7\end{array}$ & 450 & 3.06 .19 & 119 & 111 & 98 & $\begin{array}{l}\text { Coal } \\
\text { seam }\end{array}$ & 6 \\
\hline $\begin{array}{l}\text { borehole } \\
\text { No. } 8\end{array}$ & 450 & 6.06 .19 & 140 & 96 & 86 & $\begin{array}{l}\text { Coal } \\
\text { seam }\end{array}$ & 5 \\
\hline $\begin{array}{c}\text { borehole } \\
\text { No. } 9\end{array}$ & 450 & 9.06 .19 & 157 & 116 & 100 & $\begin{array}{l}\text { Coal } \\
\text { seam }\end{array}$ & 8 \\
\hline $\begin{array}{c}\text { borehole } \\
\text { No. } 10\end{array}$ & 450 & 12.06 .19 & 174 & 123 & 109 & $\begin{array}{l}\text { Coal } \\
\text { seam }\end{array}$ & 7 \\
\hline
\end{tabular}

It was found that the initial length of boreholes drilled into the coal seam roof along the bedrock was close to a design one $-70 \mathrm{~m}$. At the same time, successive measurements indicated that boreholes length decreased within 20 days by $15 \%$ (Fig. 4), and the methane concentration at their wellheads by $3 \%$.

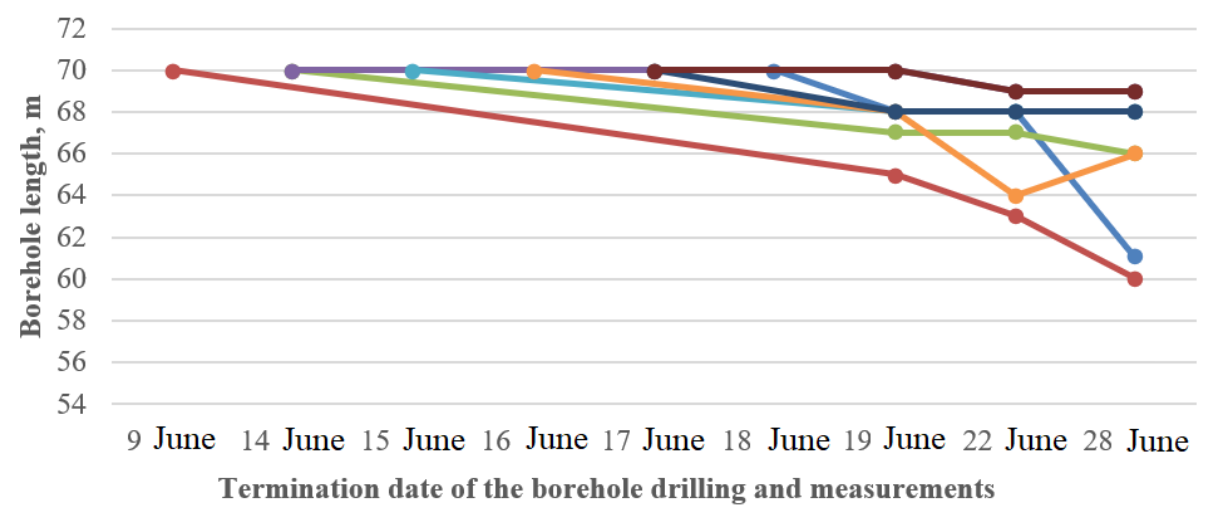

\begin{tabular}{|c|c|c|}
\hline$\rightarrow$ Bush 10 borehole 1 & $\longrightarrow$ Bush 6 borehole 1 & - Bush 8 borehole 1 \\
\hline$\multimap$ Bush 8 borehole 2 & $\rightarrow$ Bụsh 8 borehole 3 & $\rightarrow$ Bush 9 borehole \\
\hline
\end{tabular}

Fig. 4. Over time length variation of boreholes drilled into the coal seam roof.

The boreholes drilled into the coal seam floor were flooded, which probably led to their recorded length of $6-19 \mathrm{~m}$ with a design depth of $93-150 \mathrm{~m}$ (Fig. 5). Over the observations time interval the recorded distance from the interface between the media - the water mirror was reduced to $80 \%$. At the same time, the methane concentration at the wellheads decreased by $8 \%$. 
The recorded length of inclined directional boreholes drilled into the coal seam quantified $38-140 \mathrm{~m}$ (Fig. 6). Their length decreased within 20 days by $75 \%$ and methane concentration at their wellheads by $10 \%$.

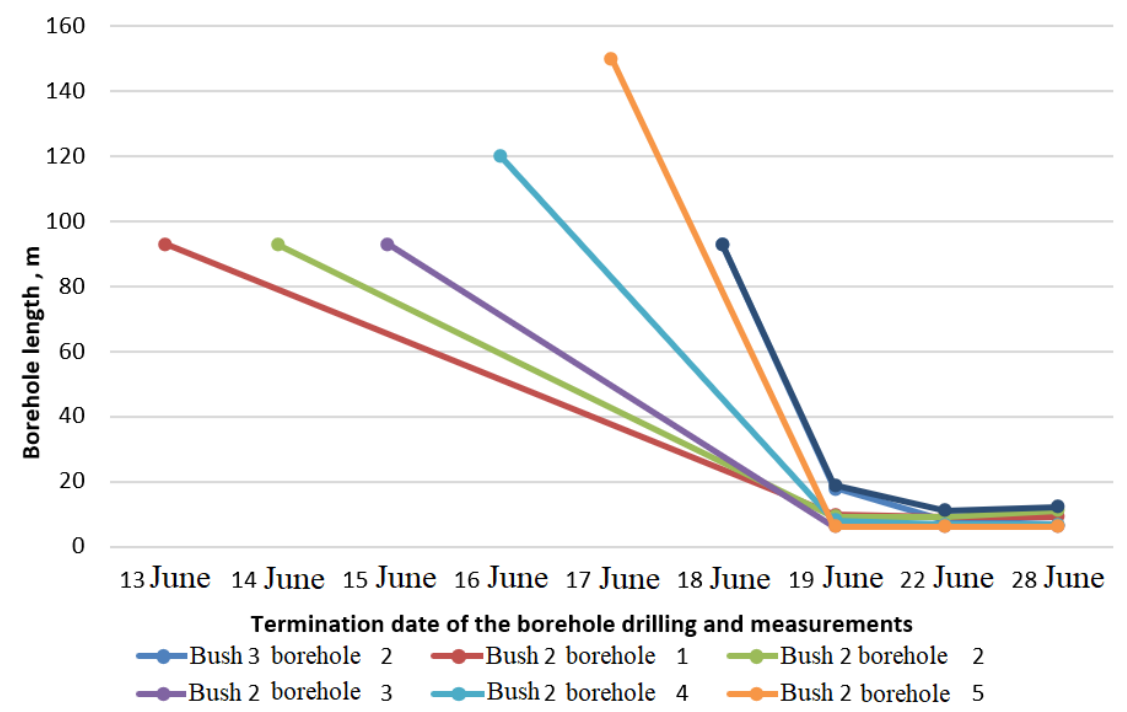

Fig. 5. Over time length variation of boreholes drilled into the coal seam floor.

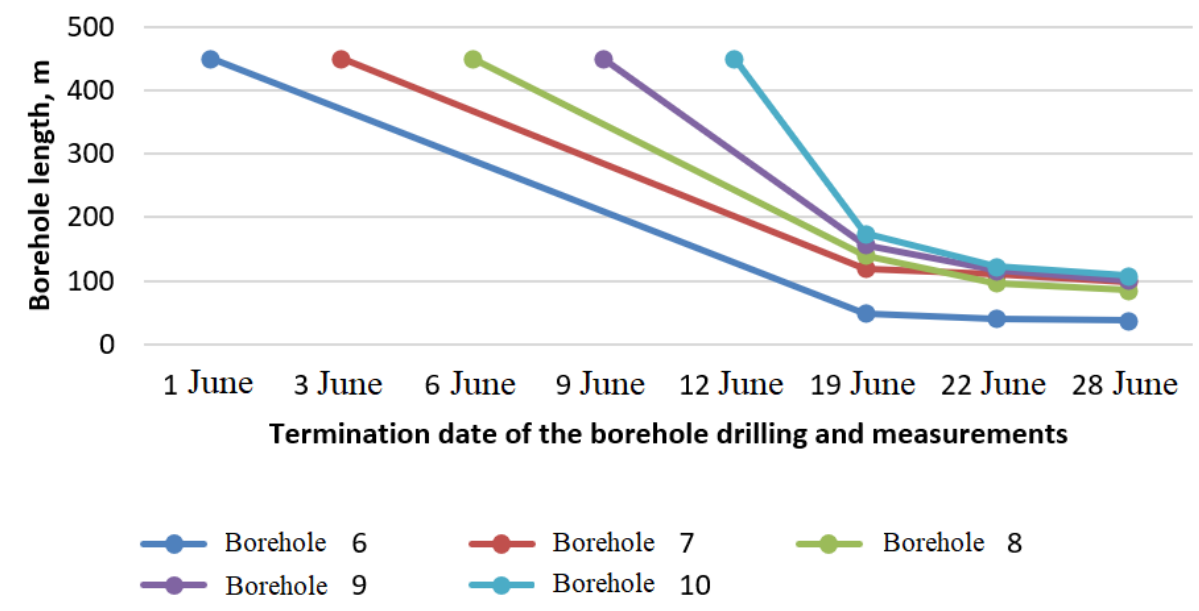

Fig. 6. Over time length variation of boreholes drilled into the coal seam.

\section{Conclusion}

The analysis of obtained results demonstrated that amplification factor of the recorded signals depends on the borehole geometry, the methane content in it, water cut and rock pressure. It was found that the rational values of the amplification factors for boreholes drilled into the coal seam roof constituted 3-4; into the floor - 7-8, into the coal seam - 5-6. The obtained results can be used for coal seams degasification methods perfection and mining work safety measures improvement. 


\section{References}

1. O.V. Tailakov, A.I. Smyslov, E.A. Utkaev, GIAB, 8, 291-293 (2004)

2. O.V. Tailakov, D.N. Zastrelov, et al., Science-intensive technologies for the development and use of mineral resources, 6, 363-366 (2020)

3. O.V. Tailakov, E.A. Utkaev, M.P. Makeev, Science-intensive technologies for the development and use of mineral resources, 6, 366-370 (2020)

4. O.V. Tailakov, M.P. Makeev, S.V. Sokolov, Science-intensive technologies for the development and use of mineral resources, 6, 38-42 (2020)

5. Yu.V. Sopov, Eurasian Scientific Association, 1, 13-16 (2016) 